CASSOWARY volume 4 (1): 101-111

ISSN : 2614-8900

E-ISSN : 2622-6545

Program Pascasarjana Universitas Papua, https://pasca.unipa.ac.id/

\title{
Analisis faktor penentu kinerja pegawai Rumah Sakit Umum Daerah Kabupaten Manokwari
}

\author{
Sopia Manusawai, Jacob Manusawai, Anton S. Sinery* \\ Program Studi S2 Ilmu Lingkungan, Program Pascasarjana, Universitas Papua \\ Jalan Gunung Salju, Amban, Manokwari, Kode Pos 98314, Papua Barat, Indonesia. \\ *Email: anton_sineri@yahoo.com
}

\begin{abstract}
The aims of this research is to study the defining factor of employee performance on RSUD Manokwari, spesifically the impact of leadership, cultural organization, and work motivation to the employee performance. The methods that is used in this research was descriptive methods with interview and obervation. The interview was conducted with the employee of RSUD Manokwari while observing the performance of them. The respondences of this research are 202 people who work in RSUD Manokwari, consisting of ASN staff and the honorary staff. The result shows that leadership take a positive effect on administration staff performance in RSUD Manokwari. Also, the organisation culture and work motivation have a positive impact on the Administration staff in RSUD Manokwari.
\end{abstract}

Keywords: performance, leadership, organisation culture, work motivation, RSUD Manokwari

\section{PENDAHULUAN}

Permasalahan kinerja erat kaitannya dengan permasalahan bagaimana kepemimpinan dilaksanakan, dan bagaimana cara mengembangkan budaya organisasi yang serta bagaimana motivasi dapat meningkatkan kinerja karyawan pada sebuah institusi.

Menurut Nawawi (2003: 19) budaya kerja adalah kebiasaan yang dilakukan berulang-ulang oleh dalam suatu organisasi, pelanggaran terhadap kebiasaan ini memang tidak ada sangsi yang tegas, namun dari pelaku organisasi secara moral telah menyepakati bahwa kebiasaan tersebut merupakan kebiasaan yang harus ditaati dalam rangka pelaksanaan pekerjaan untuk mencapai tujuan. Budaya kerja akan bermanfaat dalam organisasi saat masing-masing saling membutuhkan sumbang saran dari teman sekerjanya, namun budaya kerja ini akan berakibat buruk apabila dalam instansi tersebut mengeluarkan ego masing-masing karena perbedaan pandangan.

Rumah Sakit Umum Daerah (RSUD) Kabupaten Manokwari merupakan RSUD dengan Tipe C sesuai dengan Keputusan Menteri Kesehatan Republik Indonesia Nomor: 531/MENKES/SK/VI/1996 tanggal 5 juni 1996. RSUD ini merupakan peninggalan Pemerintah Kolonial Belanda yang dibangun pada Tahun 1950 yang berdiri di atas lahan seluas \pm $37.424 \mathrm{~m} 2$ dengan total luas bangunan $\pm 9.283 \mathrm{~m} 2$ (Lakip 2019: 3). Rumah Sakit Umum Daerah Kabupaten Manokwari terletak di Kota Manokwari dan 
stratetgis bagi pelayanan kesehatan masyarakat di 9 distrik atau kecamatan (Distrik Warmare, Prafi, Manokwari Barat, Timur, Utara, Selatan, Tanah Rubu, Masni dan distrik Sidey (LAKIP 2019: 3).

Sejak pendiriannya berbegai upaya telah dilakukan baik peningkatan layanan kerja melalui peningkatan sarana dan prasarana, sumber daya manusia dan berbagai upaya lainnya guna peningkatan status rumah sakit ini. Namun demikian sejauh ini belum terlihat adanya perubahan yang signifikan khususnya status akreditasi rumah sakit ini yang diduga dipengaruhi oleh berbagai faktor diantaranya kepemimpinan, budaya organisasi dan motivasi kerja.

Tujuan penelitian ini adalah untuk memahami faktor penentu kinerja staf administrasi RSUD Manokwari khususnya pengaruh kepemimpinan, budaya organisasi dan motivasi kerja terhadap kinerja staf administrasi RSUD Kabupaten Manokwari

\section{MATERI DAN METODE}

Penelitian ini berlangsung selama selama 5 (lima) bulan (Bulan Februari 2020 sampai dengan Juni 2020) dan bertempat di RSUD Kabupaten Manokwari.

Peralatan dan bahan yang digunakan dalam penelitian ini terdiri atas data, tali sheet, kamera, computer (labtop), software SPSS versi 17, LAKIP RSUD Kabupaten Manokwari tahun 2019 dan data administrasi kepegawaian RSUD Manokwari. Selanjutnya subjek dalam penelitian adalah staf administrasi pada RSUD Kabupaten Manokwari. Metode yang digunakan dalam penelitian ini adalah metode deskriptif kualitatif. Metode ini di rancang melalui langkahlangkah penelitian sebagai berikut yaitu operasional variabel penentuan jenis dan sumber data. Variabel yang dimati dalam penelitian ini adalah aspek manajemen khususnya kepemimpinan, budaya organisasi kerja dan motivasi kerja.

Metode yang digunakan dalam penelitian ini adalah metode deskriptif dengan teknik wawancara dan observasi. Wawancara dilakukan dengan responden yang merupakan staf administrasi RSUD Kabupaten Manokwari disertai pengamatan terkait kinerja RSUD Manokwari. Responden yang ditentukan dalam penelitian adalah semua staf administrasi RSUD Manokwari yang berjumlah 202 orang. Jumlah responden tersebut terdiri atas atas staf berstatus ASN maupun tenaga honorer.

Prosedur penelitian ini mencakup tahap persiapan penelitian dan pelaksanaan penelitian. Sebelum dilakukan penelitian terlebih dahulu dilakukan koordinasi dengan pimpinan RSUD Manokwari terkait penyampaian informasi rencana penelitian. Pelaksanaan penelitian dilakukan dengan melakukan wawancara dengan staf administrasi RSUD Manokwari melalui daftar pertanyaan yang teah disiapkan. Selanjutnya dilakukan pengelompokan responden sesuai karakteristik responden. Setelah dilakukan wawancara selanjutnya dilanjutkan pada responden lainnya sampai responden terakhir. Hasil wawancara akan diisi dalam daftar pertanyaan yang menggunakan skala likert untuk mengukur pendapat responden. Jumlah pertanyaan yang disiapkan sebanyak 48 pertanyaan yang terbagi atas 4 komponen pertanyaan masing-masing untuk pemimpin, budaya organisasi, motivasi kerja dan kinerja. Skala likert dimaksud dibangun atas skala Likert masing-masing sangat setuju (SS) bobot 5, setuju (S) bobot 4, kadang-kadang setuju (KKS) bobotnya 3, Tidak Setuju (TS) bobotnya 2, dan Sangat Tidak Setuju (STS) bobotnya 1. 
Data hasil wawancara dan pengamatan selanjutnya dianalisis secara deskriptif dan ditampilkan dalam ventuk tabel dan gambar. Selanjutnya untuk menilai hubungan antar faktor terkait kinerja dilakukan analisis regresi linear berganda. Untuk proses analisis linear dimaksud akan dilakukan uji

HASIL DAN PEMBAHASAN Karakteristisk Pegawai

Sebagian besar pegawai berusia antara 41 sampai dengan 50 tahun yang merupakan usia produktif bagi ASN di lingkungan RSUD Kabupaten Manokwari sebagaimana Tabel 1. reabilitas.

Tabel 1. Karakteristik pegawai berdasarkan usia

\begin{tabular}{cccc}
\hline No. & Usia & Jumlah & Persen $(\%)$ \\
\hline 1. & $20-30$ tahun & 0 & 0,00 \\
2. & $31-40$ tahun & 74 & 36,63 \\
3. & $41-50$ tahun & 81 & 40,09 \\
4. & $51-60$ tahun & 47 & 23,26 \\
\hline \multicolumn{2}{r}{ Total } & 202 & 100,00 \\
\hline
\end{tabular}

ASN di lingkungan RSUD Kabupaten Manokwari lebih banyak didominasi oleh pegawai berjenis kelamin perempuan sebagaimana pada Tabel 2 .

Tabel 2. Karakteristik pegawai berdasarkan jenis kelamin

\begin{tabular}{clcc}
\hline No & \multicolumn{1}{c}{ Jenis Kelamin } & Jumlah & Persen $(\%)$ \\
\hline 1. & Laki-laki & 49 & 24,25 \\
2. & Perempuan & 153 & 75,74 \\
\hline \multicolumn{2}{c}{ Total } & 202 & 100
\end{tabular}

Secara umum pegawai yang berpendidikan SPK (Diploma) mendominasi ting- kat pendidikan ASN di RSUD Kabupaten Manokwari sebagaimana pada Tabel 3.

Tabel 3. Karakteristik pegawai berdasarkan pendidikan

\begin{tabular}{clcc}
\hline No & \multicolumn{1}{c}{ Pendidikan } & Jumlah & Persen $(\%)$ \\
\hline 1. & SMA/SPK & 61 & 30,19 \\
2. & Diploma & 87 & 43,06 \\
3. & Sarjana & 39 & 19,30 \\
4. & Pascasarjana & 15 & 7,42 \\
\hline \multicolumn{2}{r}{ Total } & 202 & 100 \\
\hline
\end{tabular}

Masa kerja pegawai RSUD Manokwari berkisar antara 11 sampai dengan 20 tahun mendominasi pengalaman kerja pegawai di RSUD ini sebagaimana pada Tabel 4. Pegawai RSUD Manokwari bergolongan III mendominasi pangkat/golongan pegawai di RSUD sebagaimana pada Tabel 5. Karakteristik pegawai berdasarkan eselon didominasi eselon IV, namun demikian lebih sedikit untuk eselon I sesuai dengan jenis jabatan di RSUD sebagaimana Tabel 6. 
Tabel 4. Karakteristik pegawai berdasarkan pengalaman kerja

\begin{tabular}{|c|c|c|c|}
\hline No & Pengalaman Kerja & Jumlah & Persen $(\%)$ \\
\hline 1. & $1-10$ tahun & 45 & 22,27 \\
\hline 2. & $11-20$ tahun & 84 & 41,58 \\
\hline 3. & 21 - 30 Tahun & 67 & 28,21 \\
\hline 4. & $31-40$ Tahun & 16 & 7,92 \\
\hline & Total & 202 & 100 \\
\hline
\end{tabular}

Tabel 5. Karakteristik pegawai bersarkan golongan

\begin{tabular}{cccc}
\hline No & Golongan & Jumlah & Persen $(\%)$ \\
\hline 1. & II & 69 & 34,16 \\
2. & III & 109 & 53,96 \\
3. & IV & 24 & 11,88 \\
\hline & Total & 202 & 100 \\
\hline
\end{tabular}

Tabel 6. Karakteristik pegawai berdasarkan esalon

\begin{tabular}{clcc}
\hline No & & Uraian & Jumlah \\
\hline 1. & Esalon II & 1 \\
2. & Esalon III & & 4 \\
3. & Esalon IV & & 7 \\
4. & Non Eselon & 190 \\
\hline
\end{tabular}

Karakteristik pegawai berdasarkan fungsional didominasi oleh tenaga umumnya rumah sakit sebagaimana perawat yang menjadi ciri dari kondisi

Tabel 7.

Tabel 7. Karakteristik pegawai berdasarkan fungsional

\begin{tabular}{clcc}
\hline No & & Uraian & Jumlah \\
\hline 1. & Doketr Ahli & 14 \\
2. & Dokter Umum & 13 \\
3. & Dokter Gigi & 1 \\
4. & Apoteker & 10 \\
5. & Paramedis Perawat & 154 \\
6. & Paramedis Bidan & 49 \\
\hline
\end{tabular}

Karakteristik pegawai berdasarkan paramedis didominasi oleh tenaga analis

kesehatan dibandingkan dengan paramedis lainnya sebagaimana Tabel 8 .

Tabel 8. Karakteristik pegawai berdasarkan paramedis

\begin{tabular}{|c|c|c|}
\hline No & Uraian & Jumlah \\
\hline 1. & Analisis Kesehatan & 17 \\
\hline 2. & farmasi & 6 \\
\hline 3. & Gizi & 6 \\
\hline 4. & Fiosioterapi & 3 \\
\hline 5. & Kesling & 3 \\
\hline 6. & Radiologi & 4 \\
\hline 7. & Tehnik & 3 \\
\hline
\end{tabular}


Karakteristik pegawai berdasarkan administrasi kerja didominasi oleh tenaga kebersihan (petugas kebersihan) dibandingkan sopir dan petugas keamanan sebagaimana Tabel 9.

Tabel 9. Karakteristik pegawai berdasarkan administrasi kerja

\begin{tabular}{|c|c|c|}
\hline No & Uraian & Jumlah \\
\hline 1 & Sopir & 4 \\
\hline 2 & Satpam & 6 \\
\hline 3 & Petugas Kebersihan & 45 \\
\hline
\end{tabular}

Secara umum semua program kerja RSUD Manokwari dapat dilakukan secara dengan target anggaran, walaupun tidak mencapai 100\%. Sebagaimana Tabel 10.

Tabel 10. Realisasi Anggaran Kinerja Tahun 2019

\begin{tabular}{|c|c|c|c|c|c|}
\hline No & Uraian & Anggaran & realisasi & Sisa & $\begin{array}{c}\text { Persen } \\
(\%)\end{array}$ \\
\hline \multirow[t]{7}{*}{1} & $\begin{array}{l}\text { Pelayanan administrasi } \\
\text { perkantoran }\end{array}$ & & & & 82 \\
\hline & $\begin{array}{l}\text { a. Penyediaan jasa su- } \\
\text { rat menyurat }\end{array}$ & 3.000 .000 & 1.059 .000 & 1.941 .000 & \\
\hline & $\begin{array}{l}\text { b. Penyediaan alat tulis } \\
\text { kantor }\end{array}$ & 967.247 .100 & 1.074047 .100 & 1.200 .000 & \\
\hline & $\begin{array}{l}\text { c. Penyediaan barang } \\
\text { cetak dan pengadaan }\end{array}$ & 89.744 .200 & 89.647 .960 & 96.240 & \\
\hline & $\begin{array}{l}\text { d. Penyediaan kompo- } \\
\text { nen instalasi. }\end{array}$ & 126.855 .80 & $126.855 .300,000$ & 500.00 & \\
\hline & $\begin{array}{l}\text { e. Rapat-rapat koordi- } \\
\text { nasi dan konsultasi } \\
\text { keluar daerah }\end{array}$ & 54.854 .800 & $38,758,354$ & 16.096 .446 & \\
\hline & $\begin{array}{l}\text { f. Penyediaan jasa pe- } \\
\text { layanan administrasi } \\
\text { perkantoran }\end{array}$ & & & & \\
\hline \multirow[t]{3}{*}{2} & Program Peningkatan & 137.500 .000 & 122.948 .332 & 14.551 .668 & 92 \\
\hline & $\begin{array}{l}\text { Sarana dan Prasarana } \\
\text { Paraturan }\end{array}$ & & & & \\
\hline & 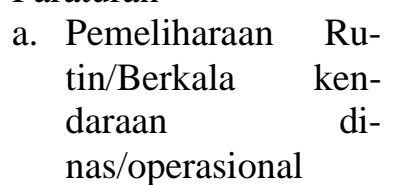 & 1.566 .800 .000 & 1.510 .73 & 56.050 & \\
\hline 3 & $\begin{array}{l}\text { Program Obatan dan } \\
\text { pembekalan kesehatan } \\
\text { a. Pengadaan obat dan } \\
\text { pembekalan } \\
\text { kesehatan }\end{array}$ & 428.860 .000 & 367.920 .234 & 60.939 .766 & 80 \\
\hline 4 & $\begin{array}{l}\text { Program pengadaan, } \\
\text { peningkatan sarana dan } \\
\text { prasarana rumah sakit } \\
\text { rumah sakit jiwa rumah }\end{array}$ & 5.296 .293 .288 & 4.888.771.354 & 407.521 .934 & 80 \\
\hline
\end{tabular}


sakit paru-paru rumah sakit mata.
a. Pembangunan runah 2.860.000.000 2.589.642.200
270.357 .800 sakit (DAK)
b. Pengadaan alat-alat kesehatan rumah sa- kit
36.001 .410 .000
$33.303 .049,949$
2.698 .360 .051
c. Pembangunan lahan parker dan per- tamanan
68.213.234.816
63.469.959.079
4.743.275.737

\section{Analisis Hubungan Faktor Penentu Kinerja}

Analisis Hubungan Faktor Penentu Kinerja sebaimana ditunjukkan pada Tabel 11.

Tabel 11. Hubungan Faktor Penentu Kinerja

\begin{tabular}{lcccc}
\hline & Kepemimpinan_x1 & $\begin{array}{c}\text { Budaya Organ- } \\
\text { isasi_x2 }\end{array}$ & $\begin{array}{c}\text { Motivasi } \\
\text { kerja_x3 }\end{array}$ & Kinerja_y \\
\hline Valid & 202 & 202 & 202 & 202 \\
Mean & 3,644 & 3.924 & 3.693 & 3,591 \\
Std. Deviation & 0.550 & 0.434 & 0.417 & 0.449 \\
Minimum & 1,85 & 2,15 & 2,01 & 1,89 \\
Maximum & 5 & 5 & 4,92 & 4,56 \\
\hline
\end{tabular}

Hasil analisis sebagaimana terlihat pada Tabel 11 menunjukan bahwa beberapa pernyataan yang diajukan dijawab oleh seluruh responden (202), sehingga tidak terdapat data yang missing. Variabel kinerja (Y) terdiri atas 9 (sembilan) pernyataan, dimana semua pernyataan tersebut diberi skor skala likert dengan skor minimum 1 dan skor maksimum adalah 5, hasilnya dijumlahkan sehingga memperoleh hasil rata-rata skor sebesar 3,591 dan nilai tertinggi atas jawaban responden terhadap seluruh pernyataan variabel kinerja adalah sebesar 4,56 dan nilai terendah adalah 1,89 . Hal tersebut menunjukan bahwa kinerja ASN di RSUD Manokwari berada pada kategori cukup baik. Variabel gaya kepemimpinan $\left(\mathrm{X}_{1}\right)$ terdiri atas 13 (tiga belas) pernyataan, semua pernyataan tersebut diberi skor dengan skala likert dengan skor minimum 1 dan skor maksimum adalah 5, hasilnya dijumlahkan sehingga memperoleh hasil rata-rata skor sebesar 3,644 dan nilai tertinggi sebesar 5 dan nilai terendah adalah 1,85. Hal tersebut menunjukan bahwa bahwa kepemimpinan pada RSUD Kabupaten Manokwari berada pada kategori cukup baik. Variabel budaya organisasi $\left(\mathrm{X}_{2}\right)$ terdiri atas 14 (empat belas) pernyataan, dimana semua pernyataan tersebut diberi skor dengan skala likert dengan skor minimum 1 dan skor maksimum adalah 5, hasilnya dijumlahkan sehingga memperoleh hasil rata-rata skor sebesar 3.924 dengan nilai tertinggi atas jawaban responden terhadap seluruh item pernyataan variabel kinerja adalah sebesar 5 dan nilai terendah adalah 2,15 . Hal tersebut emnunjukan bahwa budaya organisasi pada ASN di RSUD Kabupaten Manokwari berada pada kategori cukup baik. Variabel motivasi kerja $\left(\mathrm{X}_{3}\right)$ terdiri atas 12 (dua belas) pernyataan, dimana semua pernyataan tersebut diberi skor dengan skala likert dengan skor minimum 1 dan skor maksimum adalah 5, hasilnya dijumlahkan sehingga 
memperoleh hasil rata-rata skor sebesar 3.693 dengan nilai tertinggi atas jawaban responden terhadap seluruh item pernyataan variabel kinerja adalah sebesar 4,92 dan nilai terendah adalah
2,01. Hal tersebut menunjukan bahwa motivasi kerja pada ASN di RSUD Kabupaten Manokwari berada pada kategori cukup baik.

Tabel 12. Uji Reabilitas

\begin{tabular}{lcc}
\hline \multicolumn{1}{c}{ Variabel Penelitian } & alpha cronbach's & Keterangan \\
\hline Kinerja $(\mathrm{Y})$ & 0.724 & Reliabel \\
Kepemimpinan $\left(\mathrm{X}_{1}\right)$ & 0.819 & Reliabel \\
Budaya organisasi $\left(\mathrm{X}_{2}\right)$ & 0.804 & Reliabel \\
Motivasi $\left(\mathrm{X}_{3}\right)$ & 0.674 & Reliabel \\
\hline
\end{tabular}

Tabel 12 menunjukkan bahwa semua variabel penelitian memiliki nilai alpha cronbach's antara 0.67 s.d. 0.81, dengan demikian semua variabel penelitian berada pada kategori reliabel dan dapat dilanjutkan untuk dilakukan analasis regresi linier berganda sebagaimana terlihat pada Tabel 13.

Table 13. Hasil Analisis Regresi Linier Berganda

\begin{tabular}{lcccc}
\hline \multicolumn{1}{c}{ Variabel Penelitian } & $\begin{array}{c}\text { Koefisien } \\
\text { Regresi }\end{array}$ & Nilai “t” & $\begin{array}{c}\text { Korelasi } \\
\text { Parsial }\end{array}$ & Sig \\
\hline Kepemimpinan $\left(\mathrm{X}_{1}\right)$ & 0.048 & 0,565 & 0.058 & 0.565 \\
Budaya organisasi $\left(\mathrm{X}_{2}\right)$ & 0.134 & 1,111 & 0.113 & 0.269 \\
Motivasi kerja $\left(\mathrm{X}_{3}\right)$ & 0.498 & 4,672 & 0.430 & 0.000 \\
Konstanta & $=1,048$ & & & \\
$\mathrm{~F}_{\text {hitung }}$ & $=15,306$ & Sig $=0.000$ & \\
Adjusted $\mathrm{R}^{2}$ & $=0.302$ & & & \\
\hline
\end{tabular}

\section{Pengujian Hipotesis Simultan (Uji F)}

Hipotesis penelitian yang diajukan adalah kepemimpinan, budaya organisasi dan motivasi kerja secara simultan berpengaruh terhadap kinerja pegawai lingkungan RSUD Kabupaten Manokwari. Pengujian hipotesis dilakukan dengan membandingkan tingkat sig ( $p$ value) dengan tingkat alpha yang dipersyaratakan yaitu 0.05 . apabila sig $(p$ value $)<$ alpha 0.05 maka $\mathrm{H}_{0}$ ditolak dan $\mathrm{H}_{\mathrm{a}}$ diterima apabila sig ( $p$ value) > alpha 0.05 maka $\mathrm{H}_{0}$ diterima dan $\mathrm{H}_{\mathrm{a}}$ ditolak. Hasil analisis menunjukan bahwa nilai signifikansi ( $p$ value) sebesar 0.000 lebih kecil dari 0.05 (alpha yang dipersyaratkan), dengan demikian $\mathrm{H}_{0}$ ditolak dan $\mathrm{H}_{\mathrm{a}}$ diterima yaitu kepemimpinan, budaya organisasi dan motivasi kerja secara simultan mempunyai pengaruh terhadap kinerja pegawai di lingkungan RSUD Kabupaten Manokwari.

\section{Pengujian Hipotesis Parsial (Uji “t”)}

Hipotesis penelitian yang diajukan adalah gaya kepemimpinan, budaya organisasi dan motivasi kerja secara parsial mempunyai pengaruh terhadap kinerja pegawai di lingkungan RSUD Kabupaten Manokwari. Pengujian hipotesis dilakukan dengan membandingkan tingkat sig ( $p$ value) dengan tingkat alpha yang dipersyaratakan yaitu 0.05 , apabila sig ( $p$ value) < alpha 0.05 maka $\mathrm{H}_{0}$ ditolak dan $\mathrm{H}_{\mathrm{a}}$ diterima apabila sig $(p$ value $)>$ alpha 0.05 maka $\mathrm{H}_{0}$ diterima dan $\mathrm{H}_{\mathrm{a}}$ ditolak.

Berdasarkan dengan analisis dengan menggunakan program SPSS versi 17 for windows, diketahui bahwa pengaruh 
kepemimpinan $\left(\mathrm{X}_{1}\right)$ terhadap kinerja pegawai di lingkungan RSUD Kabupaten Manokwari. Hasil analisis diperoleh nilai sig ( $p$ value) sebesar 0.574 . Dengan demikian nilai sig ( $p$ value) lebih besar dari 0.05 (alpha yang dipersyaratkan) dengan demikian $\mathrm{H}_{0}$ diterima dan $\mathrm{H}_{\mathrm{a}}$ ditolak yaitu kepemimpinan mempunyai pengaruh positif dan signifikan terhadap kinerja pegawai di lingkungan RSUD Kabupaten Manokwari.

Pengaruh budaya organisasi $\left(\mathrm{X}_{2}\right)$ terhadap kinerja pegawai di lingkungan RSUD Kabupaten Manokwari. Hasil analisis diperoleh nilai sig ( $p$ value) sebesar 0.269 . Dengan demikian nilai sig ( $p$ value) lebih besar dari 0.05 (alpha yang dipersyaratkan) dengan demikian $\mathrm{H}_{0}$ diterima dan $\mathrm{H}_{\mathrm{a}}$ ditolak yaitu budaya organisasi mempunyai pengaruh positif dan signifikan terhadap kinerja pegawai di lingkungan RSUD Kabupaten Manokwari.

Pengaruh motivasi kerja $\left(\mathrm{X}_{3}\right)$ terhadap kinerja pegawai di lingkungan RSUD Kabupaten Manokwari. Hasil analisis diperoleh nilai sig ( $p$ value) sebesar 0.000 . Dengan demikian nilai sig ( $p$ value) lebih kecil dari 0.05 (alpha yang dipersyaratkan) dengan demikian $\mathrm{H}_{0}$ ditolak dan $\mathrm{H}_{\mathrm{a}}$ diterima yaitu motivasi kerja mempunyai pengaruh positif dan signifikan terhadap kinerja pegawai di lingkungan RSUD Kabupaten Manokwari.

\section{Koefisien Korelasi Parsial}

Korelasi parsial digunakan untuk mengetahui variabel-variabel bebas yang mempunyai pengaruh yang dominan terhadap variabel terikat. Untuk mengetahui variabel bebas yang mempunyai pengaruh yang dominan terhadap variabel terikat digunakan nilai korelasi parsial atau nilai sig yang diperoleh ( $p$ value). Nilai korelasi parsial yang paling besar atau nilai sig ( $p$ value) yang paling kecil merupakan variabel bebas yang mempunyai pengaruh yang dominan terhadap variabel terikat.

Berdasarkan dengan hasil analisis sebagaimana pada Tabel 13 di atas menunjukkan bahwa variabel motivasi kerja yang mempunyai pengaruh dominan terhadap kinerja pegawai di lingkungan RSUD Kabupaten Manokwari. Hal tersebut ditunjukkan dengan nilai korelasi parsial sebesar 0.430 dan nilai sig ( $p$ value) sebesar 0.000 .

\section{Pengujian Analisis Model Regresi Linear}

\section{Uji Multikolinieritas}

Uji multikolinieritas merupakan keadaan dimana terdapat korelasi yang sangat tinggi antara variabel bebas dalam persamaan regresi, dikatakan bahwa multikolinier yang tinggi (mendekati sempurna) diantara dua atau lebih variabel berarti jika diantara variabel bebas yang digunakan sama sekali tidak berkorelasi, tetapi tidak lebih tinggi dari r, maka bisa dikatakan tidak terjadi multikolinieritas. Model regresi yang baik seharusnya tidak terjadi korelasi diantara variabel bebas. Untuk mengetahuinya dengan melihat VIF (Variance Inflation Factor) dalam output program SPSS versi 17 for Window. Multikolinier yang tinggi (mendekati sempurna) diantara dua atau lebih variabel berarti jika diantara variabel bebas yang digunakan sama sekali tidak berkorelasi, tetapi tidak lebih tinggi dari r, maka bisa dikatakan tidak terjadi multikolinieritas. Nilai VIF 0,1 dan VIF kurang dari 10, maka dapat disimpulkan bahwa dalam model regresi tidak terjadi gejala multikolinearitas.

Berdasarkan dengan hasil analisis dengan menggunakan program SPSS 
versi 17 for Window diperoleh nilai VIF (variance inflation factor) variabel kepemimpinan sebesar 1.526, budaya organisasi sebesar 1.935 dan variabel motivasi kerja sebesar 1.393. Hasil analisis menunjukkan bahwa nilai VIF (variance inflation factor) masing-masing variabel bebas memiliki nilai lebih besar dari 0.1 dan kurang dari 10 . Dengan demikian dapat disimpulkan bahwa dalam model regresi tidak terjadi gejala multikolinieritas.

\section{Uji Heterokedastisitas}

Uji Heterokedastisitas merupakan suatu keadaan yang masing-masing kesalahan pengganggu mempunyai varian yang berlainan. Heterokedastisitas diuji dengan menggunakan uji koefisien korelasi rank spearman, yaitu mengkorelasikan antara absolut residual hasil regresi dengan semua variabel bebas. Dalam penelitian ini, uji heteroskedastisitas diuji dengan mendiagnosa diagram plot residual, yakni membandingkan regression studentized residual dengan nilai prediksi yang menggambarkan perubahan distribusi residual dikaitkan dengan perubahan nilai prediksi variabel independen. Apabila distribusi residual meningkat tidak diikuti oleh naiknya nilai prediksi, dalam arti nilai prediksi variabel-variabel independen tetap konstan, maka perubahan itu menunjukkan bahwa tidak terjadi heteroskedastisitas atau terjadi homoskedastisitas. Di samping itu apabila probabilitas hasil korelasi lebih kecil dari 0,05 (5\%), maka persamaan regresi mengandung heterokedastisitas dan sebaliknya berarti non heterokedastisitas atau homokedastisitas. Model regresi yang baik adalah tidak terjadi heterokedastisitas (Santoso, 2000 dalam Aziz 2001).

Hasil pengujian dengan melihat grafik scatterplat di mana sumbu $\mathrm{X}$ adalah $\mathrm{Y}$ yang telah diprediksi dan sumbu Y adalah residual yang telah distandarized. Hasil garfik terlihat tidak terdapat pola yang jelas dan titik-titik menyebar di atas dan di bawah angka nol pada sumbu $\mathrm{Y}$ dari masing-masing variabel bebas sehingga tidak mengandung gejala heterokedastisitas.

\section{Uji Autokorelasi}

Autokorelasi dapat didefinisikan sebagai hubungan antara anggota observasi yang diurutkan menurut waktu atau ruang (Gujarati, 2003 dalam Brahmasari, 2004). Konsekuensinya dari adanya autokorelasi dalam suatu model regresi adalah variasi sampel tidak dapat menggambarkan variasi populasinya. Lebih jauh lagi, model regresi yang dihasilkan tidak dapat digunakan untuk menaksir nilai variabel dependen pada variabel indenpenden itu. Untuk mendeteksi adanya masalah autokorelasi akan dilihat dari indikator Durbin-Watson (DW), nilai DW tabelnya untuk tingkat $\alpha=5 \%$, apabila $\mathrm{dU}<\mathrm{d}<4-\mathrm{dU}$, maka tidak terjadi autokorelas.

Tabel 14. Hasil Analisis Menggunakan Anova

\begin{tabular}{cccccc}
\hline Model & Sum of Squares & DF & Mean Square & F & Sig \\
\hline Regression & 6.463 & 3 & 2.154 & 15.306 & 000 \\
Residual & 13.513 & 96 & 141 & & \\
Total & 19.976 & 141 & & & \\
\hline
\end{tabular}


Tabel 15 Hasil Analisis Menggunakan Anova

\begin{tabular}{lcccccccc}
\hline & N & Range & Min' & Max' & & Mean & \multicolumn{2}{c}{$\begin{array}{c}\text { Std. devi- Variance } \\
\text { ation }\end{array}$} \\
\cline { 2 - 9 } & Statistic Statistic & Statistic & Statistic & Statistic & Std.Error & Statistic & Statistic \\
\hline Kepemimpinan_X1 & 202 & 3,15 & 1,85 & 5.00 & 3.6440 & 05260 & 54596 & 298 \\
BudayaOrganisasi_X2 & 202 & 2,85 & 2,15 & 500 & 3.9244 & 04336 & 43365 & 188 \\
Motivasi Kerja_X3 & 202 & 2,91 & 2,01 & 4,92 & 3.6927 & 04172 & 41720 & 174 \\
Kinerja_Y & 202 & 2,67 & 1,89 & 4,56 & 3.5911 & 04492 & 44920 & 202 \\
Valid N (listwise) & & & & & & & & \\
\hline
\end{tabular}

Hasil analisis regresi maupun anova menunjukan bahwa faktor kepemimpinan mempunyai pengaruh yang cukup signifikan dan positif terhadap kinerja pegawai di lingkungan RSUD Kabupaten Manokwari. Hal ini berarti bahwa seorang pemimpin cukup efektif untuk mempengaruhi para pegawai sehingga komitmen kepada tujuan dan misi institusi tercapai, dengan demikian cara-cara perilaku pemimpin dalam mengarahkan pegawai berpengaruh terhadap peningkatkan kinerja.

Kepemimpinan mempunyai fungsi penentu arah dalam pencapaian tujuan sebagai juru bicara organisasi, komunikator, mediator dan integritor. Perilaku kepemimpinan memiliki kecenderungan pada dua hal yaitu konsiderasi atau hubungan dengan bawahan dan hasil yang dicapai. Kecenderungan kepemimpinan menggambarkan hubungan yang akrab dengan bawahan misalnya bersikap ramah, membantu dan membela kepentingan bawahan, bersedia menerima konsultasi bawahan dan memberikan kesejahteraan.

Kecenderungan seorang pemimpin memberikan batasan antara peranan pemimpin dan bawahan dalam mencapai tujuan, memberikan instruksi. pelaksanaan tugas di instansi. Cara pemimpin merupakan motivasi kerja bagi pegawai yang berada dibawahnya. Menurut Umar (2004) bahwa perilaku kepemimpinan berpengaruh terhadap kinerja. Hal ini berarti bahwa gaya kepemimpinan seseorang dalam sebuah institusi dapat berpengaruh terhadap kinerja pegawainya.

Selanjutnya dari hasil pengujian hipotesis yang kedua dalam penelitian yang menyatakan bahwa budaya organisasi mempunyai pengaruh yang signifikan terhadap kinerja pegawai di lingkungan RSUD Kabupaten Manokwari. Hal ini menunjukkan bahwa budaya institusi dapat meningkatkan kinerja pegawai. Budaya institusi adalah suatu sistem nilai yang diperoleh dan dikembangkan oleh isntitusi serta kebiasaan dan falsafah dasar pendirinya, yang terbentuk menjadi aturan yang digunakan sebagai pedoman dalam berfikir dan bertindak dalam mencapai tujuan institusi

Keutamaan budaya organisasi merupakan pengendali dan arah dalam membentuk sikap dan perilaku manusia yang melibatkan diri dalam suatu kegiatan institusi. Aziz (2001), Moekijat (2001); Budaya mempunyai kekuatan yang berpengaruh pada individu dan kinerjanya bahkan terhadap lingkungan kerja.

Soekarso dan Cecep Hidayat (2010) menyebutkan bahwa elemen-elemen budaya organisasi atau institusi adalah nilai, kepercayaan, pendapat, sikap dan norma. Budaya pada dasarnya merupakan totalitas pola tingkah laku sosial, seni, keyakinan, kelembagaan, dan 
produk kerja, serta pemikiran manusia lainnya dari suatu komunitas atau populasi tertentu, atau merupakan nilai yang disumbangkan oleh orang dalam suatu kelompok yang cenderung bertahan dalam waktu yang relatif lama, meskipun anggota kelompoknya mengalami perubahan. Demikian halnya dengan hasil pengujian terhadap hipotesis ketiga yang diajukkan dalam penelitian yang menyatakan bahwa motivasi kerja mempunyai pengaruh yang signifikan dan positif terhadap kinerja pegawai dilingkungan RSUD Kabupaten Manokwari. Hal ini menunjukan bahwa motivasi kerja mempunyai pengaruh yang signifikan dan positf terhadap kinerja ASN di lingkungan RSUD Kabupaten Manokwari dapat diterima.

\section{KESIMPULAN}

Kepemimpinan berpengaruh positif terhadap kinerja staf administrasi di RSUD Kabupaten Manokwari. Demikian halnya dengan budaya organisasi dan motivasi kerja keduanya berpengaruh positif terhadap kinerja pegawai di lingkungan institusi RSUD Kabupaten Manokwari.

\section{DAFTAR PUSTAKA}

Arifin, M. (2010). Kepemimpinan dan Motivasi Kerja. Sekses Offset, Yogyakarta 2010. Kinerja Pegawai, Penerbit. Kretakupa, Makassar

Brahmasari, I. (2004). Pengaruh Variabel Budaya Perisahan Terhadap Komitmen Karyawan dan Kinerja Perusahan Kelompok Penerbitan Pers Jawa Pos. Disertase Universitas Aerlangga, Surabaya

Ermayanti, D., Thoyib A. (2001). Pengaruh Faktor Motivasi terhadap Prestasi Kerja Karyawan pada Kantor Perum Perhutani Unit II Surabaya.
Kartini, K. (2008). Gaya Kepemimpinan. Penerbit Gava Media.Yogyakarta.

Moekijat. (2001). Dasar-dasar Motivasi, Pioner Jaya, Bandung.

Nawawi, H. (2003). Kepemimpinan Mengevektifkan Organisasi., Buku I Universitas Terbuka/UPI-Y A I Jakarta.

Nimran, U. (2004). Perilaku Organisasi, Cetakan Ketiga, CV. Citra Media, Surabaya.

Siagian, S., P., (2002). Kiat Meningkatkan Produktivitas Kerja, Cetakan Pertama, PT. Rineka Cipta, Jakarta.

Soekarso, C., H. (2010). Teori Kepemimpinan, Penerbit, Mitra, Wacana Media.

Suharsimi, A. (1996). Prosedur Penelitian, Rineke Cipta. Jakarta

Tika., H., M., Pabundu. (2006). Budaya Organisasi dan Peningkatan Kinerja Perusahaan. Cetakan Pertama. PT. Bhumi Aksara, Jakarta.

Yasin, A. (2001). Kepemimpinan dalam Pengembangan Organisasi, Jurnal Lintasan Ekonomi. Ekonomi Universitas Brawijaya Malang. Volume 18 Nomor 1. Malang. 